\title{
A Closer Look at Extensive Reading in Omani Public Schools: Current Practices and Teachers' Perceptions
}

\author{
Al Seyabi Fawzia ${ }^{1} \&$ Al Rashdi Salwa ${ }^{2}$ \\ ${ }^{1}$ College of Education, Sultan Qaboos University, Sultanate of Oman \\ ${ }^{2}$ Ministry of Education, Sultanate of Oman \\ Correspondence: Al Seyabi Fawzia, Department of Curriculum and Instruction, Sultan Qaboos University, \\ Sultanate of Oman. Tel: 968-2414-3959. E-mail: fawzia@squ.edu.om
}

Received: May 2, 2016 Accepted: June 19, 2016 Online Published: June 20, 2016

doi: 10.5539/elt.v9n8p93 URL: http://dx.doi.org/10.5539/elt.v9n8p93

\begin{abstract}
The present study aims at identifying the current practices regarding the implementation of extensive reading in Omani public schools. The study employed a content analysis sheet to analyze the extensive reading work of 300 students. Semi-structured interviews were also held with 15 teachers and 5 regional supervisors from Al-Dakhilyia Governorate. Results of the study revealed that the frequency of reading amongst students is very low as $53 \%$ of the students read only once a semester and they often read the same type of genre. The results also showed that most of the English language teachers chose the same reading materials for their students regardless of the students' interests or proficiency level. To show evidence of reading, students often wrote responses to questions in their notebooks. As for assessment, teachers did not assess students based on the frequency of reading or the difficulty level of the questions chosen. Teachers responded to students' work by giving them a general mark rather than providing descriptive comments or giving recommendations on what to read next. Drawing upon the findings, recommendations to bring about better practices regarding extensive reading are provided.
\end{abstract}

Keywords: extensive reading, Oman, current practices, perceptions

\section{Introduction}

In foreign language contexts where the amount of L2 input is very limited, it becomes essential for educators to look for ways to increase students' opportunities of exposure to the foreign language. With this in mind, many schools, colleges and other teaching/learning centers in different parts of the world have incorporated extensive reading programs in their institutions where students are expected to read "extensively" outside the classroom and respond to what they read. According to Bamford and Day (2004), "Good things happen to students who read a great deal in the new language. They become better and more confident readers, they write better, their listening and speaking abilities improve, and their vocabularies get richer (p. 1). Hedge (2001) has pointed to the increasing interest in extensive reading and has attributed this to the insights from second language acquisition studies and the role and nature of input in the learning process.

Clarity (2007) defines extensive reading as reading a lot for pleasure. Extensive reading should be done at a comfortable "easy" level for the students and the main goal is to read in a stress-free environment. Learners should not be looking up every new word in the dictionary. The goal is to create fluency and enjoyment in the reading process. Finally, extensive reading is something that should take place over a continuous period of time.

Davis (1995) presents a more comprehensive definition to help guide teachers in implementing extensive reading programs. According to him, an extensive reading program is a supplementary class library scheme attached to an English course in which pupils are given the time, encouragement, and materials to read pleasurably, at their own level, as many books as they can without the pressures of testing or marks.

The literature on extensive reading reports many advantages for its implementation. Extensive reading provides opportunities for students to meet the language in its natural context and see how it works in extended discourse beyond the language met in textbooks (The Extensive Reading Foundation, 2011). This is especially important in countries like Oman where students' exposure to the target language is mainly limited to classroom or school settings. Several studies have also pointed to the role that extensive reading programs play in promoting positive 
attitudes towards reading (Sheu, 2003; Nishino, 2007; Morgado, 2009; Yamashita, 2008; Nakanishi \& Uedo, 2011). Research done in the area of extensive reading has also proved that it has positive effects on enhancing students' vocabulary (Konopak et al., 1987) and developing students' sense of independence and autonomy (Imrie, 2007; Lake \& Holster, 2011). In addition, it exposes the learners to L2 in different contexts through the use of authentic materials and develops their general, world knowledge (Guo, 2012).

There is no agreement about how best to implement extensive reading programs. The traditional implementation treats extensive reading as a separate and an isolated activity from the rest of the language classes. Others propose that extensive reading should be integrated into the curriculum. Yu (1993) claims that if not incorporated into the curriculum, reading 'tends to be spasmodic, haphazard and unrewarding, with the result that [students] will eventually give up reading' (p. 3). Thus, a good extensive reading program will allow for at least some reading to take place in class, as recommended by Macalister (2008). The conclusion that can be drawn is that there is no particular way of implementing extensive reading, but that schemes should be 'developed by teachers to suit local circumstances,' (Green, 2005, p. 310).

As for the Omani EFL context, the Ministry of Education (MoE) embraces the application of extensive reading from grade five upwards. According to the Students' Assessment Handbook (SAH), extensive reading refers to the reading done by individual students on their own initiative and with a minimum of outside support. The adoption of this approach reflects the fact that "The ability to read independently is a key learning outcome in itself, and also has a potentially beneficial impact on other aspects of the English language, such as vocabulary,' (Ministry of Education, 2014/2015, p. 21). Therefore, the Ministry provides a framework for teachers to follow in order to develop this important skill.

This framework includes a five-point rating scale that is used to award marks for the independent reading that learners do. Awarding these marks focuses on:

(1) reading as many texts as possible, and

(2) carrying out related tasks (generic tasks) at as high a level as possible.

The tasks that are developed by the English specialists at the Omani Ministry of Education are quite generic as they can be adapted for use with any text. In addition, they can be adapted for different students of different levels of achievement and different ages. These tasks aim at developing students' reading as well as other language skills.

The document provided by the MoE to be used with extensive reading consists of three sections. The first one describes the task difficulty, which ranges from bronze (the easiest) to platinum (the most demanding). The second section is task options which explains the generic task that can be used with each type of text i.e. fiction, fact, history, etc. The last section provides the students with the reading record form. In this form, students write a brief description of the texts they have read, the titles, and the codes of the generic tasks they have chosen to respond to. Both teacher and students are expected to sign this form at the end of each semester. The table below gives an example of the generic tasks assigned for the gold reading level.

Table 1. Gold-level tasks as described in the MoE's Student Assessment Handbook (SAH)

\begin{tabular}{|c|c|c|c|c|}
\hline $\begin{array}{l}\text { Code } \\
\text { No. }\end{array}$ & $\begin{array}{l}\text { Before } \\
\text { reading }\end{array}$ & $\begin{array}{l}\text { After } \\
\text { reading }\end{array}$ & Task type & Instructions \\
\hline GD 1 & * & & Want to know & $\begin{array}{l}\text { Look at the title and make a list of questions that you } \\
\text { would like the text to answer. }\end{array}$ \\
\hline GD 2 & $*$ & & Think & $\begin{array}{l}\text { Look at the title and say/write your opinion about the } \\
\text { topic of the text and why. }\end{array}$ \\
\hline GD 3 & & $*$ & Summary & Write a short summary of the text or part of the text. \\
\hline GD 4 & & * & Like/dislike (a) & $\begin{array}{l}\text { Describe and explain your reactions (positive or } \\
\text { negative) to the text. }\end{array}$ \\
\hline GD 5 & & * & Like/dislike (b) & $\begin{array}{l}\text { Write a letter/e-mail to a friend. Recommend that } \\
\text { he/she should read the text that you have read. }\end{array}$ \\
\hline GD 6 & & * & What next? & $\begin{array}{l}\text { Think about the continuation of the story. What will } \\
\text { happen next? }\end{array}$ \\
\hline GD 7 & & * & Imagine (a) & $\begin{array}{l}\text { Describe how the story would be different in an } \\
\text { Omani context. }\end{array}$ \\
\hline GD 8 & & * & Imagine $(b)$ & Write a reply to a letter or e-mail. \\
\hline
\end{tabular}




\section{Statement of the Problem}

In recognition of the importance of extensive reading, the Ministry of Education in Oman states that learners from grades 5-10 "will be able to tackle extended texts with increasing confidence and understanding," (Ministry of Education, 2011). As a result, the Ministry has instructed teachers to use extensive reading starting from grade five.

In spite of the benefits revealed in the literature and the Ministry's guidelines, there is a widespread observation that is often expressed by teachers and educationalists in general about the very little reading that students do. There also seems to be a lack of understanding on the part of school teachers of the MoE's requirements regarding extensive reading. There is also empirical evidence that suggests students are having problems with reading (Al Seyabi and Tuzlukova, 2015) and are performing poorly in reading tests (Al Khamisi, 2014). Analyzing tenth graders' exam marks of the academic year (2013/2014) shows a serious lack of success in both vocabulary and reading sections. Anecdotal evidence based on the analysis of 238 exam papers revealed that $87 \%$ of the students got less than $50 \%$ in the vocabulary section and $52 \%$ of the students scored less than $50 \%$ in the reading skill. Although these results are based on students' performance in intensive reading classes, the literature on extensive reading does point to a direct link between the way the latter is practiced and students' overall language performance in general and reading in particular (Horst, 2005; Yamashita, 2008; Stapleton \& Tanaka, 2007). Hedge (2001) emphasized that while intensive reading trains students in certain strategies like predicting content or guessing the meaning of unknown words from the context, it is only through extensive reading learners can get considerable practice to operate these strategies independently.

These observations combined have made it necessary to examine how extensive reading is handled in Omani schools. We believe that understanding the current situation will help improve the way extensive reading is dealt with in the Omani public education system, hence maximizing its benefits and its potential influence in developing students' overall proficiency levels.

The present study aims at investigating the current practices regarding the use of extensive reading programs in Omani public schools by focusing on one grade level, which is grade 10. This is done through a) examining samples of students' responses to extensive reading tasks and b) conducting interviews with teachers and regional supervisors. More specifically, the study aims to answer the following research questions:

1) What are the current practices regarding the implementation of extensive reading in grade ten in public schools in Oman?

2) What are the EFL teachers' and EFL supervisors' perceptions of different aspects related to extensive reading?

\section{Theoretical Background}

\subsection{Characteristics of Extensive Reading}

According to Robb and Susser (1990), extensive reading is a language teaching/learning approach that is characterized by:

1) Reading large quantities of materials.

2) Reading for general understanding.

3) Reading for the purpose of pleasure.

4) Reading that is individualized.

5) Reading that is mostly done outside the boundaries of the classroom and where books aren't discussed in class.

Even though extensive reading is characterized by reading large quantities, there is no consensus on how much "extensive" is. Bamford and Day (2004) suggest that one book a week is recommended for general benefits and for the sake of establishing a reading habit. The same is recommended for vocabulary acquisition (Nation \&Wang, 1999).

\subsection{Extensive Reading Materials}

Choosing the appropriate materials is of a fundamental role in the success of any extensive reading program. If students are to read extensively, they need to be provided with interesting materials that are approachable and are well within the students' proficiency levels.

Jacobs (2014) explains that the reading materials should be at the students' independent reading level. He divides 
the reading materials into three levels: the frustrational level, the instructional level and the independent level. According to Jacobs, in the frustrational level, the materials are difficult to be comprehended even with the help of the teacher. In the instructional level, the materials are beyond the students' understanding, yet they can approach them with the assistance of the teacher, their peers, dictionaries or any other resources. As for the independent level, the students can understand the materials without any outside support whether from the teacher or from peers by using their background knowledge or the clues provided in the context.

Bamford and Day (2002) go further to suggest that even the materials that are lower than the students' independent level are suitable for extensive reading because:

1) Less challenging materials boost the students' confidence especially that students who start reading in a new language may lack confidence.

2) Easy materials allow students to understand what they read and this in turn gives the students the opportunity to use their cognitive abilities in other activities such as noticing how the language works and making connections between what they read and their lives.

3) Teachers can add the language challenge element to the easy-to-read materials by introducing extra activities.

Another element that needs to be taken into consideration is selecting authentic materials that make students read genuinely (Hedge, 2001). According to Hedge, choosing graded readers will gradually help develop students' vocabulary; they will not need to overuse their dictionaries, which will consequently offer them the opportunity to practice their inference skills. Nuttall (2005) further adds that the chosen materials must be short, varied and appealing. These elements will foster the desire to read in L2.

In addition to selecting materials that are suitable for the students' linguistic competence, the element of interest is a vital one as well. Many students feel reluctant to read in L2 unless the materials are interesting. Students' interests may be affected by the topics and text types. Some may like to read about animals, while others prefer to read about space. Moreover, students' interest can change. The role of the teacher is essential in introducing new topics and text types. Hedge (2001) asserts that students' interest is a key element in choosing texts.

There are plenty of methods available for teachers to find out what their students prefer to read. Questionnaires used at the beginning of an extensive reading program can reveal so much about students' interests. Besides, teachers can use the students' previous reading records to identify their interests. However, teachers need to be cautious not to provide their students with materials that are way beyond their linguistic competence level.

In addition, having a purpose for reading when selecting the materials is just as important as considering what interests students (Hedge, 2001). Students should have a range of reading purposes in order to develop their confidence in approaching various texts without having to understand every single word in the text. Creating a purpose will motivate students to read.

To implement extensive reading, teachers need to have primary resources that consist of a collection of varied reading materials: books, magazines and a good place to display them in class. Not having these resources demands that the students find their own materials to read which is considered to be difficult in EFL contexts. The perfect set contains materials that match the students' linguistic competence level besides their interests. Robb and Susser (1990) recommend that teachers include graded readers, children's literature, high interest-low vocabulary readings as well as popular writing in their collections to meet different interests and varied levels.

\subsection{Relevant Empirical Studies}

Numerous research studies have been conducted to examine the impact of extensive reading programs on various aspects of EFL learning. Al-Hamoud and Schmitt (2009) compared an intensive reading class against an extensive reading one in a college level course in Saudi Arabia. The students participating in their study had studied EFL for 6 years in school. The researchers reported that using the extensive reading approach was challenging due to many factors: some of the students' competency level was weak, the environment did not support extensive reading and the course was short. The results indicated that even though the extensive reading was applied in a challenging environment, it was as good as intensive reading in improving students' reading comprehension, reading speed and vocabulary gain. Moreover, the participants in the extensive reading program reported more positive attitudes towards their class, their learning and towards reading compared to the intensive reading group.

In a study that was carried in 2008, Iwahori investigated the effectiveness of ER on the reading rates of 37 average level high school students in Japan. The participants' English proficiency was at a beginning level based 
on the reports from the Society for Testing English Proficiency test. The participants were provided with 107 graded readers and 30 comic books, which made a total of 137 books. Each student would choose 28 books to read as homework according to their interest. The graded readers were chosen with a range of basic vocabulary from 200-1000 words. A pretest was given to the students before starting the program. During the study, the students had to read, keep a reading record with a brief comment about what they have read. At the end of the 7 weeks program, the students took a posttest. Analysis of the results proved that ER is effective in developing students' reading rates and English language proficiency.

Similar findings were reported by research conducted in primary schools. Cheng and Juan (2008) examined the possibility of using ER as a remedial program to improve the learning performance and attitude of three 4th grade elementary school EFL underachievers in Taiwan. The researchers carried out 50 ER sessions during one semester; each lasted for half an hour. To assure the reliability of the data collected, several instruments were used, mainly observations, interviews, review of documents, running records of oral reading, researchers' journals, a letter identification test and two high frequency word recognition tests. The materials were selected with lots of visual support to provide contextual clues for guessing the meaning of unknown words and to attract the students. In addition, the context was within the participants' age and intellectual level. The books were not too long to make sure that the students wouldn't get bored. The analysis of the data showed promising results. The participants improved in the letter identification ability and in word knowledge. Due to the quantity of exposure to ER, they also improved in their knowledge of high frequency words. In addition, the ER program had some affective gain as well. The participants' learning attitude changed positively and they were more confident in learning English.

There were also a few studies that investigated extensive reading from the teachers' perspective. Macalister (2008) involved 36 teachers from a preparation course at a language-teaching center in New Zealand in a study that investigated both their attitudes to extensive reading and their practices. The results showed that even though teachers expressed positive beliefs about the influence of extensive reading, these beliefs didn't result in the inclusion of ER in the classroom program. Similar results were reported by Haider and Akhter (2012) who explored the current practices that EFL teachers in Bangaldesh followed with regard to extensive reading. The researchers found that although the teachers have generally exhibited positive beliefs about the benefits of extensive reading, the techniques they adopted in their classes mostly encouraged intensive reading. Bamford and Day (1997) comment on how students' limited extensive reading could be a consequence of traditional, intensive approaches to foreign language reading instruction.

\section{Methodology}

\subsection{Population and Sample}

The present study comprised two distinct populations: English teachers and regional supervisors. The first population consisted of male and female teachers teaching grade ten in Al Dakhilyia Governorate in the academic school year 2014/2015. Interviews were conducted with 15 teachers ( 7 males and 8 females).

The second population was the regional supervisors in the governorate. Out of 21 supervisors working in the Directorate of Education in Dhakeleya, 5 supervisors (three female supervisors and two male supervisors) were interviewed.

\subsection{Research Instruments}

\subsubsection{The Content Analysis Sheet}

The content analysis sheet was designed based on the literature on extensive reading and the instructions provided by the Ministry of Education available in the SAH. The sheet was used to investigate the current practices regarding the implementation of extensive reading in grade ten. The content analysis sheet focused on analyzing four aspects. The first part of the sheet included general information such as the number of readings done by the student and his/her achievement level according to the end of the first semester results. The second part of the content analysis sheet was used to get data about the reading materials the students of grade ten read: the type of readings, the genres they read and the length of the texts. The third part aimed at collecting information about the pre-reading tasks that the students responded to and the form of their responses. The fourth part analyzed the post-reading tasks and the form of responses to these tasks. The sheet had a total of 28 items.

A panel of experts validated the primary version of the content analysis sheet and modifications were made to the sheet based on their feedback. To ensure reliability, the validated version of the content analysis sheet was piloted on the work of five grade ten students. Inter-rater reliability was used to ascertain the reliability of the analysis sheet. The correlation coefficient of the content analysis sheet was $r=.92$, which was considered a high 
level of inter-rater consistency.

\subsubsection{The Semi-Structured Interviews}

Interviews were conducted with 15 English language teachers of grade ten: 8 female teachers and 7 male teachers. Ten teachers reported that they implemented extensive reading as homework, while the other 5 asked the students to read at their own pace at home and later on tested them in class by giving them some tasks. The second interview was conducted with 5 regional supervisors including 3 female supervisors and 2 male supervisors.

Questions of the interview have mainly aimed at identifying teachers' and supervisors' perceptions of different issues relevant to extensive reading such as its effectiveness, the instructions that the MoE provided and the training that teachers received, if any. There were also questions that sought teachers' and supervisors' views on the type of practices revealed through the content analysis.

\section{Results and Discussion}

\subsection{Current Practices based on Content Analysis}

To examine the current practices regarding extensive reading in the Omani context, a content analysis sheet was used to analyze the work of 300 grade ten students (160 male and 140 female students). During the interviews, teachers and supervisors were asked about their views of these practices.

Results are provided with regard to the following points:

1) Number of readings done by a student per semester.

2) Who chooses the reading materials.

3) Type of materials read by students.

4) Genres read by students.

5) Type of pre-reading tasks done by students.

6) Form of responses to pre-reading tasks.

7) Type of post-reading tasks done by students.

8) Form of responses to post-reading tasks.

9) Types of records kept by students.

10) Type of feedback provided to students.

11) Criteria used for assessing students' performance.

Table 2. Frequencies of the number of readings done by students each semester

\begin{tabular}{lll}
\hline No of times per semester & Frequency & Percent \\
\hline Once & 159 & 53.0 \\
$*$ Twice & 117 & 39.0 \\
$* *$ Three times & 24 & 8.0 \\
Total No of readings & 465 & 100.0 \\
\hline
\end{tabular}

* This number is doubled $\quad * *$ This number is tripled.

With regard to the number of readings done by students each semester, Table 2 shows that $53 \%$ of the students read once only while $39 \%$ of the students read twice a semester and $8 \%$ of the students read three times a semester which makes a total of 465 readings.

All of the 5 regional supervisors interviewed agreed that the students should read at least three times a semester. One regional supervisor stated that three is the minimum number but those students who are interested and see the benefit of reading can read more. According to Bamford and Day (2004), a book a weak is recommended for general benefits and establishing a reading habit. The same is suggested by Nation and Wang (1999) for vocabulary acquisition. 
Table 3. Frequencies of who chooses the reading materials

\begin{tabular}{lll}
\hline Who chooses readings & Frequency & Percent \\
\hline Teacher & 41 & 54.7 \\
Students & 34 & 45.3 \\
Total & 75 & 100.0 \\
\hline
\end{tabular}

Table 3 above clearly shows that $54.7 \%$ of the teachers chose the reading materials for their students while $45.3 \%$ of them allowed the students to choose what to read based on their interests. However, it was also noted that the teachers who chose the materials tend to give the same reading material for all the students -which is mostly a class reader provided by the Ministry of Education-regardless of their students' interests or their proficiency levels. Teachers gave different justifications for choosing the reading materials for their students. Some stated that they chose the same reader for the whole class because this makes it easier to check students' work and give them feedback.

The regional supervisors made it clear that the teacher shouldn't interfere in the choice of the reading materials. All agreed that the teacher could guide the students and provide suggestions for them only. One regional supervisor commented that the materials should be of different levels so the teacher can only guide the students to choose the reader that suits their level. The teacher is a guide; he/she can help the students to choose but not to choose for them.

According to Robb and Susser (1990), the students will enjoy reading materials of their choice more than the ones assigned by others, a teacher for example. Murphy (2010) focused on the idea that humans pursue activities that they enjoy and try to avoid the ones they consider uninteresting or unpleasant. Similarly, Lee (2007) noted that self-selection of readings is a key factor in the successful implementation of any extensive reading program. Bamford and Day (1998) on the other hand, reported several advantages for using a class reader. According to them, teachers feel they have more control over the reading process and can easily check that students are in fact doing the reading. This is especially important when teachers have low-level learners who need as much guidance as possible. A combination of both approaches might be necessary in response to the diversity in students' needs and proficiency levels.

Table 4. Frequencies of the type of materials read by students

\begin{tabular}{lll}
\hline Type of materials & Frequency & Percent \\
\hline Story & 425 & 91.4 \\
Newspaper & 7 & 1.5 \\
Magazine & 32 & 6.9 \\
Letter/e-mails & 0 & 0.0 \\
Books & 1 & 0.2 \\
Novels & 0 & 0.0 \\
Total & 465 & 100.0 \\
\hline
\end{tabular}

Table 4 illustrates that short stories constituted about $91.4 \%$ of the extensive readings, whereas books made only $0.2 \%$, which is a very low percentage compared to the shorter texts. This can be explained in light of Table 3 where most teachers assigned students to read the class reader (a story).

Table 5. Frequencies of the genres read by the students

\begin{tabular}{lll}
\hline Genres & Frequency & Percent \\
\hline History & 12 & 2.6 \\
Sport & 4 & 0.8 \\
Technology & 7 & 1.5 \\
Geography & 0 & 0.0 \\
Science & 11 & 2.4 \\
Environment & 4 & 0.8 \\
\hline
\end{tabular}




\begin{tabular}{lll}
\hline Entertainment & 12 & 2.6 \\
Health & 1 & 0.2 \\
Fiction & 414 & 89.0 \\
Total & 465 & 100.0 \\
\hline
\end{tabular}

As obvious in the table above, the genre read by most of the students is fiction (89\%), whereas the least read genre is health $(1 \%)$. None of the students read on geography. This result can also be explained in light of the results presented in Table 2. Most of the students read the same articles on the same topics due to the fact the more than half of the teachers chose the reading materials for their students and that they chose the same readings for all the students.

Bamford and Day (2002) emphasized that for extensive reading to be successful, students need to be attracted to read. To do so, the texts should be as varied as possible: books, magazines, newspapers, fiction, non-fiction, texts that inform, texts that entertain, general, specialized, light, and serious.

Table 6 . Frequencies of the type of pre-reading tasks done by students

\begin{tabular}{lll}
\hline Type of tasks & Frequency & Percent \\
\hline Generic tasks & 151 & 50.3 \\
Tasks by teacher & 149 & 49.7 \\
Total & 300 & 100.0 \\
\hline
\end{tabular}

Table 6 shows that $50.3 \%$ of the students responded to generic tasks that were provided by the Ministry of Education before reading while $49.7 \%$ of them responded to tasks provided by their teachers. The latter tasks were often modified from the generic tasks. Teachers chose to adapt them based on the types of readings they selected.

Table 7. Frequencies of the form of responses to pre-reading tasks

\begin{tabular}{lll}
\hline Form & Frequency & Percent \\
\hline Written & 300 & 100 \\
Spoken & 0 & 0 \\
Combination & 0 & 0 \\
Drawing & 0 & 0 \\
\hline
\end{tabular}

All 300 students whose work was analyzed chose to respond to the pre-reading tasks only in a written form. Interviewed teachers declared that there is no time to allow students to respond to the tasks in a spoken form because time isn't allocated in the syllabus for the implementation of extensive reading although it is suggested in the Students' Assessment Handbook. Not choosing the drawing questions can be attributed to the instructions provided by the MoE. According to the instructions, the more difficult the level of the task, the higher the marks that the student gets. One regional supervisor commented that "some of the questions need more effort and time, so they should be given higher marks while the easier ones should be given less marks like drawing because they consume less time and effort".

Table 8 . Frequencies of the type of post-reading tasks done by the students

\begin{tabular}{lll}
\hline Type of tasks & Frequency & Percent \\
\hline Generic tasks & 151 & 50.3 \\
Tasks by teacher & 149 & 49.7 \\
Total & 300 & 100.0 \\
\hline
\end{tabular}

Like the case with pre-reading, $50.3 \%$ of the students responded to generic tasks while $49.7 \%$ responded to tasks provided by the teacher. 
Table 9. Frequencies of the forms of responses to post-reading tasks

\begin{tabular}{lll}
\hline Form & Frequency & Percent \\
\hline Written & 267 & 89.0 \\
Spoken & 0 & 0.0 \\
Combination of 1,2 & 0 & 0.0 \\
Drawing & 7 & 2.3 \\
Combination of 1,4 & 26 & 8.7 \\
Total & 300 & 100.0 \\
\hline
\end{tabular}

The table above ascertained the findings presented in Table 7 . It shows that $89 \%$ of the students responded to post-reading tasks in a written form. The table also demonstrates that $2.3 \%$ of the students chose to respond by drawings and $8.7 \%$ chose a combination of drawing and written form. Like the pre-reading forms, none of the students responded to the post-reading tasks in a spoken form.

Table 10. Frequencies of the type of records kept

\begin{tabular}{lll}
\hline Type of records & Frequency & Percent \\
\hline Reading records & 0 & 0.0 \\
Tasks done & 300 & 100.0 \\
Written journals & 0 & 0.0 \\
\hline
\end{tabular}

Table 10 reveals that in order to show evidence of reading, 100\% of the students kept responses to the tasks they did. None of them kept any reading records or written journals. This might be mainly attributed to the instructions provided by the Ministry of Education to keep evidence of the students' work by responding to the generic tasks, as instructed in the Students' Assessment Handbook. Robb and Susser (1990) encourage the use of record sheets kept by the students to give the teachers and students the opportunity to keep track of the reading progress.

Table11. Frequencies of the type of feedback provided to the students

\begin{tabular}{lll}
\hline Feedback & Frequency & Percent \\
\hline Grades & 292 & 97.3 \\
Descriptive & 8 & 2.7 \\
Recommendations & 0 & 0.0 \\
\hline
\end{tabular}

The results displayed in the previous table unravel a common practice that might affect the value of extensive reading and the benefits it should create. The table shows that $97.3 \%$ of the students were given grades on their responses while $2.7 \%$ only were provided with descriptive feedback beside the grades. None of the students received recommendations on what to read next. Stanley (2005) highlighted the importance of giving the students some suggestions on what to read next based on their current level and their progress with extensive reading. This is one simple method to instill the love of reading among students.

Table 12. Frequencies of the Criteria for Assessing Students' Responses

\begin{tabular}{lll}
\hline Assessment criteria & Frequency & Percent \\
\hline Language proficiency & 4 & 1.3 \\
Overall performance & 296 & 98.7 \\
Number of readings & 0 & 0.0 \\
Level of tasks done & 0 & 0.0 \\
Total & 300 & 100.0 \\
\hline
\end{tabular}

The above table summarizes the current practices with regard to how the students' responses are assessed. While 
the Assessment Handbook instructs teachers to assess students based on the number of readings they do per semester as well as the difficulty level of the tasks they choose, the analysis of students' work revealed that this was not the case. $98.7 \%$ of the students were assessed based on their overall performance while $1.3 \%$ of them were assessed on their language proficiency. This indicates that teachers might have found the assessment criteria impractical or unrealistic, as put by one of them in the interviews. Future revisions of the assessment criteria will have to take teachers' views into consideration.

\subsection{Teachers' and Supervisors' Perceptions}

\subsubsection{Teachers' Knowledge of Extensive Reading}

Most of the interviewed teachers were aware of the main principle of extensive reading, which is reading independently based on the choice of the learners. Teachers showed a good understanding of the main features of reading extensively. Some said that it is reading for pleasure; others added that it is reading to gain knowledge and to be exposed to other cultures. Still, some of them related the target of reading with responding to questions or tasks rather than with general understanding or reading for pleasure. One teacher expressed that "Extensive reading means no outside support. Students should go at home and read and respond to tasks and give it to the teacher to get feedback."

\subsubsection{Responding to Extensive Reading in Class Versus out of Class}

There were very few teachers who insisted that students carried the responses to the tasks in class. They justified their practice as a result of the students' lack of awareness of the importance of extensive reading. Teachers were worried that students would ask others at home to help them do the generic tasks or even copy the work of other students.

Teachers who asked the students to do extensive reading at home had different justifications. The majority attributed it to lack of time. They explained that they need the class time to cover the syllabus. Some claimed that their supervisors had instructed them to do this based on the Ministry's guidelines. Others were clear that when doing it at home, learners would be relaxed and the atmosphere is stress-free.

Regional supervisors, on the other hand, came to a consensus that it shouldn't be done in class at all. One supervisor stated, "It is supposed to be done at home. It is for pleasure not for assessing the students. It is to build a good relation between the students and reading."

\subsubsection{The Role of the Teacher}

In the extensive reading program, the teacher plays a significant role in encouraging the students and helping them to read (Hedge, 2001) and in checking and providing feedback on the students' work (Robb \& Susser, 1989). Only few teachers viewed the checking of students' work as the main role of the teacher. The majority were aware of their role in encouraging students to read and explaining the benefits of reading extensively as proclaimed by one teacher who stated: "I Encourage them to read by explaining the benefits.. I tell them that they are going to gain lots of things from reading; they are going to gain vocabulary, they are going to gain new information, and they are going to learn new grammatical structures."

\subsubsection{Communicating the Learning Objectives of Extensive Reading}

All of the interviewed teachers said that they discussed the importance of extensive reading with their students at the beginning of each semester. Some even added that they explained the procedure before asking the students to read. Yamanaka (2012) pointed out that teachers need to be careful when presenting extensive reading to the learners and when guiding them. The way teachers introduce extensive reading influences students' understanding of what it is and what its importance is.

\subsubsection{The Instructions Provided by the Ministry of Education}

There were disagreements between teachers and supervisors in their perceptions of the instructions provided by the Ministry of Education and the clarity of the Assessment Handbook. Most interviewed supervisors ascertained that the MoE instructions are clear and detailed. They also added that the Assessment Handbook told everything about the types of texts, the type of tasks, and the way teachers should deal with the tasks.

Teachers disagreed. The majority of the teachers interviewed came to the conclusion that the instructions provided by the Ministry were not clear to them, especially the part concerning assessment. Teachers commented that the assessment part was not convincing especially when rewarding marks according to the difficulty level of the tasks. Some also noted down the difficulty of the questions presented compared to the level of the students. One interviewed teacher commented: "The assessment is not clear to me as a teacher. The tasks are also difficult. I had to translate the tasks provided by the Ministry into Arabic and gave each student a copy." Only two out of 
the 15 interviewed teachers said that the instructions were clear to them.

Teachers have to deal with the reality of the situation where they face multiple challenges in the implementation of extensive reading such as students' low proficiency levels. In fact, most teachers expressed their unsatisfaction with the assessment criteria employed. They thought it was not fair to award marks based on the difficulty level of the tasks as the low achieving students would definitely be disadvantaged.

\subsubsection{Effectiveness of Extensive Reading}

The interviewed teachers believed that extensive reading was not achieving the intended goals with grade ten students. They attributed this to the students. Some teachers said that the students are unwilling to read extensively while others pointed out that the students ask others to do it for them. A couple of teachers talked about the negative attitudes of students and that they see extensive reading as a heavy burden. Some believed that it worked well with the high achieving students only.

On the other hand, some seemed to be more optimistic. One teacher explained that it worked better as long as students got to genuinely understand the reason why it was expected of them to do extensive reading.

Yet, the regional supervisors had a different opinion. They believed that some teachers were not implementing it appropriately as instructed by the Ministry of Education.

\subsubsection{Teacher Training}

All of the teachers maintained that they had not received any type of training regarding the implementation of extensive reading. When asked about how they decided to carry it, they all stated that they discussed it in the school with their senior teachers and colleagues. The regional supervisors supported the teachers' claim. None of the interviewed supervisors gave any type of training to their teachers. One supervisor added that she provided support only if teachers asked her for clarifications during meetings.

\section{Conclusion and Implications}

The findings of the study uncovered the current practices regarding the implementation of extensive reading in grade ten in Omani public schools. Grade ten students do not read frequently and they don't always get the opportunity to choose what to read. Students' responses to both pre and post reading tasks are also limited. Teachers responded to students' work by giving them grades rather than providing descriptive comments or giving recommendations on what to read next.

The implementation of extensive reading in Omani schools needs to be reviewed in order to provide the appropriate techniques of implementing extensive reading that correspond with the students' actual needs and with the syllabus and assessment guidelines. A change to maximize the benefits of extensive reading is vital. This change needs to combine the efforts of all change agents in education: curriculum designers, supervisors, trainers and teachers.

Although teachers were found to hold positive perceptions about the benefits of extensive reading, the techniques they follow do not meet the best practices suggested by the literature and the Assessment Handbook. To start with, to cultivate a more positive desire to read extensively among their students, it is important that teachers act as role models for the students by adopting a more active reading behavior and sharing the knowledge gained with their students. Teachers as guides and consultants whose main role is to support the learning process should give more room for students to choose their reading materials. Moreover, teachers are expected to be well prepared for the implementation of extensive reading to avoid haphazard practices. Since the orientation sessions organized at the beginning of an academic year regarding extensive reading are of a crucial role in explaining the extensive reading process and its importance, teachers should not neglect attending them. Supervisors need to play a more proactive role in clarifying issues regarding extensive reading and its practices and bridging the gap between the instructions coming from the Ministry of Education and teachers' current practices. In fact, the disagreements that the results of the study revealed between teachers' and supervisors' perceptions indicate that a review process is highly needed not only for the way extensive reading is implemented but also for the general guidelines that the Ministry of Education provides including the assessment system. For example, expecting that teachers assess students' work based on the difficulty level of the task was found to be both problematic and confusing. The fact that this was not practiced at all by teachers- based on the data analyzed- requires serious revision for this aspect of assessment.

There is a need for curriculum reform to weave extensive reading into the school curriculum to allow some space for teachers to monitor the students' progress during class time instead of only asking students to respond to generic tasks at home. This is important to insure genuine and authentic work from the students. Although it is 
important to allow flexibility of implementation according to the circumstances of each school, teachers need to be provided with very clear guidelines regarding extensive reading and its best practices. The lack of teachers' understanding of the nature of extensive reading implies that a greater attention to this is needed in language teachers' education programs.

Besides graded readers that the Ministry of Education provides, it is also important to provide every school with sufficient funds to buy books and other reading materials that cover different topics and genres. Needless to say, students who are presented with and are guided to read texts on different topics such as geography, health, science and environment are more likely to gain both knowledge and confidence to talk about these topics in class discussions. The ultimate aim is to make reading an integral part of students' daily activities and help them see its direct link to various aspects of both their language and personal gain.

\section{Acknowledgements}

The authors would like to thank all students, English teachers and supervisors from Al Dhakeleya Governorate in Oman who participated in the present study.

\section{References}

Al-Homoud, F., \& Schmitt, N. (2009). Extensive reading in a challenging environment: A comparison of extensive and intensive reading approaches in Saudi Arabia. Language Teaching Research, 13(4), 383-401. http://dx.doi.org/10.1177/1362168809341508

Al Khamisi, H. (2014). Gender gap in reading: The impact of reading self-efficacy beliefs on EFL reading achievement (Unpublished Master's thesis). Sultan Qaboos University, Oman.

Al Seyabi, F., \& Tuzlukova, V. (2015). Investigating EFL reading problems and strategies in post-basic schools and university foundation programs: A study in the Omani context. Malaysian Journal of ELT Research, $11(2), 35-51$.

Bamford, J., \& Day, R. (1997). Extensive reading: What is it? Why bother? The Language Teacher Online. Retrieved June 5, 2016, from http://jalt-publications.org/old_tlt/files/97/may/extensive.html

Bamford, J., \& Day, R. (1998). Extensive Reading in the Second Language Classroom. Cambridge: Cambridge University Press.

Bamford, J., \& Day, R. (2002). Top ten principles for teaching extensive reading. Reading in a Foreign Language, 14 (2).

Bamford, J., \& Day, R. (Eds). (2004). Extensive reading activities for language teachers. Cambridge: Cambridge University Press.

Carrell, P. L., \& Carson, J. G. (1997). Extensive and intensive reading in an EAP setting. English for Specific Purposes, 16, 47-60. http://dx.doi.org/10.1016/S0889-4906(96)00031-2

Cheng, C., \& Juan, L. (2008). Using extensive reading to improve the learning performance and attitude of elementary school remedial students. English Teaching \& Learning, 32(4), 41-83.

Clarity, M. (2007). An extensive reading program for Your ESL classroom. The Internet TESL Journal, 8(8).

Davis, C. (1995). ER: an expensive extravagance? ELT Journal, 49(4), 329-36. http://dx.doi.org/10.1093/elt/49.4.329

Green, C. F. (2005). Integrating extensive reading in the task-based curriculum. ELT Journal, 59(4), 306-311. http://dx.doi.org/10.1093/elt/cci059

Guo, S. (2012). Using authentic materials for extensive reading to promote English proficiency. English Language Teaching, 5(8), 196-206. http://dx.doi.org/10.5539/elt.v5n8p196

Haider, M. \&Akhter, E. (2012). Extensive reading in EFL classrooms at secondary schools in Bangladesh: Current practices and future possibilities. International Education Studies, 5, 126-133. http://dx.doi.org/10.5539/ies.v5n3p126

Hedge, T. (2001). Teaching and learning in the language classroom. Oxford: Oxford University Press.

Imrie, A. (2007). Autonomy across the English curriculum through extensive reading. Proceedings of the Independent Learning Association. Japan Conference: Exploring theory, enhancing practice: Autonomy across the disciplines. Kanda University of International Studies.

Iwahori, Y. (2008). Developing reading fluency: A study of extensive reading in EFL. Reading in a Foreign 
Language, 20(1), 70-91.

Jacobs, G. (2014). Selecting extensive reading materials. Beyond Words, 2(1), 112-127.

Konopak, B., Sheard, C., Longman, D., Lyman, B., Slaton, E., Atkinson, R., \& Thames, D. (1987) Incidental vs. intentional word learning from context. Reading Psychology, 8, 7-21. http://dx.doi.org/10.1080/0270271870080103

Lake, J. \& Holster, T. (2011). Developing autonomous self-regulated readers in an extensive reading program. Studies in Self-Access Learning Journal, 5(4), 394-403.

Lee, S. (2007). Revelations from three consecutive studies on extensive reading. RELC Journal, 38(2), 150-170. http://dx.doi.org/10.1177/0033688207079730

Macalister, J. (2008). Integrating extensive reading into an English for academic purposes program. The Reading Matrix, 8(1), 23-34.

Ministry of Education. (2011). The English language curriculum framework. Muscat: Ministry of Education.

Ministry of Education. (2014/2015). The students' assessment handbook. Muscat: Ministry of Education.

Morgado, N. (2009). Extensive reading: students' performance and perception. The Reading Matrix, 9(1), 31-43.

Murphy, R. (2010). Students' Progress and Attitudes in an Extensive Reading Class. In R. Reinelt (Ed.), The new decade and (2nd) FL Teaching: The initial phase (pp. 88-99). Rudolf Reinelt Research Laboratory EU Matsuyama, Japan.

Nakanishi, T., \& Ueda, A. (2011). Extensive reading and the effect of shadowing. Reading in a Foreign Language, 23(1), 1-16.

Nation, P., \&Wang, K. M. (1999). Graded readers and vocabulary. Reading in a Foreign Language, 12, 355-380.

Nishino, T. (2007). Beginning to read extensively: A case study with Mako and Fumi. Reading in a Foreign Language, 19(2), 76-105.

Nuttall, C. (2005). Teaching Reading skills in a foreign language. Macmillan Education: UK.

Robb, T., \& Susser, B. (1990). EFL extensive reading instruction: research and procedure. JALT Journal, 12 (2).

Sheu, S. (2003). Extensive reading with EFL learners at beginning level. TESL Reporter, 36(2), 8-26.

Stanley, G. (2005). Extensive reading. Retrieved from http://www.teachingenglish.org.uk/article/extensive-reading

Stapleton, P., \& Tanaka, H. (2007). Increasing reading input in Japanese high school EFL classrooms: an empirical study exploring the efficacy of extensive reading. The Reading Matrix, 7(1), 115-131.

The Extensive Reading Foundation (ERF). (2011). The extensive reading foundation's guide to extensive reading. Retrieved from www.erfoundation.org

Yamashita, J. (2008). Extensive reading and development of different aspects of L2 proficiency. Science Direct Journal, 36, 661-672. http://dx.doi.org/10.1016/j.system.2008.04.003

$\mathrm{Yu}, \mathrm{V}$. (1993). Extensive reading programs- how can they best benefit teaching and learning of English? TESL Reporter, 26(1), 1-9.

\section{Copyrights}

Copyright for this article is retained by the author(s), with first publication rights granted to the journal.

This is an open-access article distributed under the terms and conditions of the Creative Commons Attribution license (http://creativecommons.org/licenses/by/4.0/). 